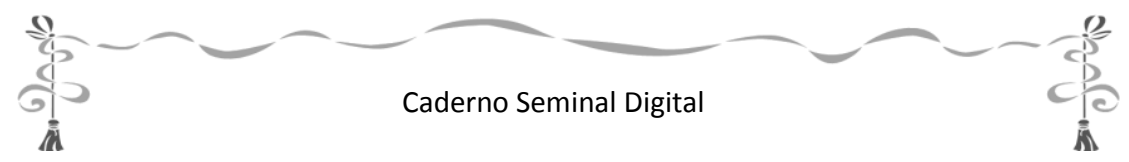

\title{
PALAVRAS DA EDITORIA
}

Eis que é publicado o volume de no 20 do Caderno Seminal Digital. Trata-se de volume temático que reúne artigos em torno das relações entre o texto literário e as imagens em movimento no teatro, no cinema e na televisão. $O$ presente volume foi produto de parceria entre um dos editores do periódico, Prof. Dr. Flavio García (UERJ), e o Prof. Dr. Leonardo Francisco Soares (UFU).

A iniciativa das Publicações Dialogarts é embalada pelo espirito extensionista, cuja meta é abrir as portas da academia e levar, aos mais diversos rincões, a produção de ciência, subsidiada por órgãos públicos e privados, portanto com a obrigação de ser mostrada ao grande público e, possivelmente, servir-lhe de base para redimensionamento de suas práticas ou de inspiração para novas invenções.

A criação dos volumes temáticos do Caderno Seminal Digital vem responder a demanda de submissões decorrentes de encontros acadêmicos no Brasil e no estrangeiro. Esclarecemos, ainda, que o conteúdo técnico-científico dos artigos, bem como sua expressão linguística, é de inteira responsabilidade dos autores.

Seguindo o objetivo de nosso projeto editorial, buscamos reunir textos de qualidade e autoridade acadêmica que possam dar suporte ao ensino na graduação e na pós-graduação, consolidando o tripé em que devem assentar-se as Universidades:

Ensino, Pesquisa e Extensão.

Flavio García e Darcilia Simões

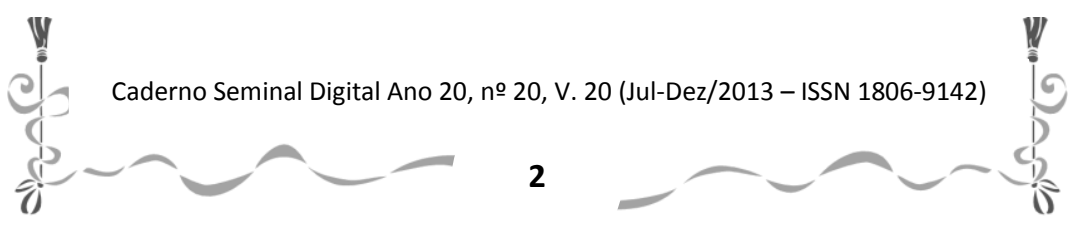

